\title{
Perceptual Exploration of Factors and Issues Affecting Adoption of E-Insurance
}

\author{
Anurag Pahuja (Corresponding Author) \\ Institute of Management Studies, Ghaziabad, India \\ E-mail: Anurag_pahuja@yahoo.co.in \\ Saloni Chitkara \\ Institute of Management Studies, Ghaziabad, India \\ E-mail: Saloni.chitkara@imsgzb.com
}

Received: May 30, 2016 Accepted: June 7, 2016 Published: June 20, 2016

doi:10.5296/csbm.v3i1.9623ＵRL: http://dx.doi.org/10.5296/csbm.v3i1. 9623

\begin{abstract}
In this ever evolving competitive environment, technology is making its foray into lives of individuals by helping them get the work done at the click of a mouse only. And the financial services industry is no exception. E-banking has already been accepted and adopted by the younger generation and those having access to internet. Another application of E-Commerce in Insurance sector i.e., E-insurance involves keeping all or any of the insurance policies in electronic mode by the policy holders, where in everything including the request, proposal, contract and negotiation is performed on-line. Despite its proclaimed benefits, there are very few users availing this service. The present study is an attempt to explore the users' perception towards E-insurance and their awareness of the concept. Using a sample size of 189 respondents based on convenience sampling, it further tries to investigate the factors affecting the adoption of E-insurance in India. Also, the study aims at finding out the potential issues and challenges associated with the usage of e-insurance.
\end{abstract}

Keywords: E-insurance, E-Insurance Adoption, Issues and Challenges 


\section{Introduction}

Insurance in India, in past 100 years, has shown a 360 degree turn from being unregulated to completely regulated; and then currently being partly deregulated industry. Private companies have shown their mark in Indian insurance sector setting a limit of 49 percent by 2014. But the largest insurance company of India i.e., "Life Insurance Company" is still owned by the government having a market share of more than 50 percent. As per the findings of World Bank regarding the insurance sector in India, it claimed that in the year 2010-11 fiscal, the life insurance industry has shown a growth of 4.2 percent as compared to general insurance industry which has shown increase by 8.1 percent. By the year 2012, Indian insurance industry was US\$72 billion. In India, only 0.2 percent of the total population was under mediclaim as compared with US nation where around 75 percent of the population is under some insurance scheme. As per the today's scenario, Insurance industry in India has shown a yearly growth rate between 32 to 34 percent making it to be the fifth largest economies around the world. At present there are 22 insurers in India offering various insurance policies. Growing level of awareness among the people about their health and safety of their loved ones has become one of the major reasons for the people to avail the insurance policies in India. Even the lucrative offers provided by insurers and the benefit of tax exemptions cannot be denied to be one of the motivational factors to get an inclination towards buying insurance policies.

\subsection{E-Insurance}

In this lightening fast business world, information technology is facilitating individuals by helping them get their work done at the click of a mouse only, without having the need to visit the brick and mortar institutions. And the world of insurance is not untouched. E-insurance is a unique and elite system that enables policy holders to buy and keep insurance policies in dematerialized or electronic form. E insurance is an insurance analogue of a demat account of a bank. Once the E- insurance account is created, all the policies; be it life insurance or health insurance can be stored in one insurance repository. This system allows the policy holders to hold all their insurance policies in an electronic format in a single account called Electronic Insurance Account (EIA). “Insurance Repository” services in India were launched by Insurance Regulatory and Development Authority (IRDA, 2013). IRDA has issued licenses to five entities to act as Insurance Repository namely National Insurance Policy Repository (NIR), Central Insurance Repository Ltd. (CIRL), and Stock Holding Corporation of India Ltd Insurance Repository (SHCILIR), CAMS Repository Services and Karvy Insurance Repository.

The prime benefit of using E-insurance is that it comes at no additional cost and is even very convenient and safe to use. Also, the customers can easily get the feedback of the other customers and can even check the viability of the policies from financial perspective with much ease and in a short duration of time. With the regularization of E-commerce, it has aimed insurers to rely heavily on it, by creating the concept of E-insurance. Though many of the insurers prefer doing their work online but still they try to seek guidance of others to take a decision. Though the technology is moving very fast but still the insurance sector in India is 
very slow in adopting E-commerce. Even the customers are reluctant to move towards this latest technology as it is a challenge for customers to get accustomed towards it.

\section{Review of Literature}

Though the rate of growth in information technology and internet infrastructure is very fast, yet the insurance sector in India is very slow in adopting e-commerce. There is innumerable research on growth and prospects of insurance industry, its financial performance, productivity and efficiency; and also the challenges faced by Indian Insurance sector (Krishnamurthy, et al., 2005; Dash \& Pany, 2013, Ernest and Young Report, 2012 and CII Report, 2015). Globally, there are a few studies that have been conducted to examine different challenges and opportunities of adopting E-commerce in various sectors viz., E-business, E-learning (distance learning mode), E-Education, E-Banking, E-insurance, E-Governance and E-Healthcare/ Healthcare Information Technology (Oblinger, 2001; Featherman, Valacich, \& Wells, 2006; Dasgupta \& Sengupta, 2002; Dwivedi \& Bharti, 2010; Hariharaputhiran, 2012; Raghunath \& Panga, 2013; Keivani et al., 2013, Phichitchaisopa \& Naenna, 2013) etc.

The application of E-commerce and adoption of internet in insurance industry specifically i.e. E-insurance is still witnessing dearth of literature. According to Aarabi \& Bromideh (2006), E-insurance, which is also known as Internet base insurance, means the use of Internet and information technology in developing, producing, distributing, and selling insurance services. More specifically, e-insurance is termed analogous to an insurance cover whose policy may be requested, presented, negotiated and concluded over the internet (online). The use of internet ensures faster dissemination of cost efficient information globally. It has changed the role of brokers from an "intermediary" to "infomediary" who conveys information to the customer (Arora, 2003).

Few of the researchers who have worked on diverse aspects of E-insurance include Arora (2003) who tried to analyze the impact and implications of E-commerce on the Insurance Industry. Alipour, Dorodi, \& Pishgahi (2011) analyzed the technical, economical, legal, operational and seasonal feasibility (using TELOS Model) of E- insurance in Iranian Asian insurance company. Where Taylor \& Cleuch (2002) tested the readiness of the agents or intermediaries towards their behavior to adopt internet technology in E-insurance, Sanayei, Torkestani, \& Ahadi (2009) assessed the Readiness of Insurance Industry for E-Commerce and E-Insurance Success in Iran.

There are various factors that affect adoption of internet in financial services industry, which include attitude, perceived behavioral control, perceived ease of use, perceived usefulness and trust (Baraghani, 2007), perceived lower costs of services (Salehi \& Alipour, 2010; Yu, 2012), reduced managerial costs and cost saving on commission to middlemen (Hiwarkar \& Khot, 2013) and performance expectancy, and perceived credibility (Yu, 2012) in context of banking. Esfahani, Ghasemi, \& Nozaripour (2014) examined the buying behavior of the customer in E- insurance and concluded that customers' mental readiness and perceived trust play an important role in buying E-insurance. Other benefits derived out of using E-insurance include improved image of the company as a leading and modern company, easy knowledge transfer among stakeholders, reduced investment costs and lowered costs for products and 
services and business expansion by eliminating geographical restrictions (Fakhri, Hajighafori, \& Jafarzadeh, 2014). It also reduces the commissions paid to the brokers or agents by providing the means to sell insurance policy directly to the customers (Odoyo \& Nyangosi, 2011; Grossman et al., 2004).

Along with perceived benefits, there are various issues that are causing the growth of adoption of internet in the insurance industry to be slow. There are certain legal and operational issues and constraints like customer privacy, sharing of database of the customers and requirement of digital signatures (Taylor \& Cleuch, 2002); lack of skills, knowledge and expertise among customers about ecommerce (Meshkat, 2012). Direct online sales pose a challenge for a significant number of insurers as customers are reluctant to buy online insurance due to various constraints related to marketing, pricing and technological and regulatory (Rakovska, 2001).

The reviewed literature suggests that though the research is being conducted in the field of E-insurance, the number of studies in India is very less, that too customer oriented studies are sparse. The present research tries to investigate individual's perception (who are using E-insurance or are willing to adopt this service) about the potential factors affecting their perception regarding adoption of E-insurance and various issues/challenges involved in using e-insurance.

\section{Objective and Hypothesis of the Study}

The research aimed at knowing the perspective of existing/potential customers, who own an insurance policy. Specifically the objectives of the study are:

- To identify various factors affecting their perception regarding adoption of E-insurance.

- To find out various potential issues/challenges perceived by customers in using E-insurance.

\subsection{Hypothesis of the Study}

Commensurate with the objectives and to understand the impact of demographic variables on the factors affecting the adoption of E-insurance and on perceived issues, the following two hypotheses have been formulated. It is hypothesized that:

H01: Various demographic variables (Age, Gender and Income Level) do not affect the respondents' perception of various factors affecting adoption of E-insurance.

H02: Various demographic variables (Age, Gender and Income Level) do not affect the respondents' perception of various issues/challenges in using E-insurance.

\section{Research Methodology}

The goal of this descriptive research is to study the perception of the customers towards benefits of e-insurance and challenges faced in using e-insurance. The present descriptive research follows the methodology as explained below. 


\section{Macrothink \\ Case Studies in Business and Management \\ ISSN 2333-3324 \\ 2016, Vol. 3, No. 1}

\subsection{Data Used}

The primary data has been collected using a well structured questionnaire comprising of two sections. Section A consists of Demographic profile of the respondents and Section B of the questionnaire comprises of total 34 statements on a seven point scale, out of which 20 statements focus on various factors affecting the adoption E-insurance and rest 14 statements reflect various issues and challenges in E-insurance.

\subsection{Sampling Method and Sample Size}

The data has been collected using non probability convenience sampling technique. In total, a group of 300 respondents which included service professionals, businessmen or self employed was targeted. The rationale behind choosing the sampling respondents was that they must be having an insurance policy and well versed with internet and online working. The questionnaire was prepared as Google doc and circulated through email to selected set of respondents. The response rate was good and we received 207 filled questionnaires back, out of which 18 were rejected due to incomplete and inconsistent responses. Out of rejected questionnaires, 14 respondents didn't have insurance policy, thereby not matching our criterion and rest 4 were incomplete. Barring these 18 questionnaires, data has been analyzed and results have been interpreted based on 189 respondents.

\subsection{Analytical Tools Used}

The demographic characteristics of the data have been presented through frequency and percentages. In order to interpret the data well, factor analysis, has also carried out meticulously employing SPSS 20. Further to check the relationship between demographic variables and various factors extracted, one way Anova has been used.

\section{Results}

A demographic profile of the respondents is presented in Table 1. It is clear from Table 1 that a 41.3 percent of the respondents are in the age group of 25-35 years and only 1 percent above 55, 57.1 percent are males and 42. 9 percent are females. 38.1 percent with annual income less than Rs. 5 lacss and 9.5 percent in the income group of 10-15 lacs. 
Table 1. Demographic profile of respondents

\begin{tabular}{|l|l|l|l|}
\hline Demographic parameter(variable) & Description & $\mathrm{N}$ & Frequency (\%) \\
\hline Age (years) & $18-25$ & 31 & 16.4 \\
\cline { 2 - 4 } & $25-35$ & 78 & 41.3 \\
\cline { 2 - 4 } & $35-45$ & 69 & 36.5 \\
\cline { 2 - 4 } & $45-55$ & 9 & 4.8 \\
\cline { 2 - 4 } & Above 55 & 2 & 1.1 \\
\hline \multirow{5}{*}{ Gender } & Male & 108 & 57.1 \\
\cline { 2 - 4 } & Female & 81 & 42.9 \\
\hline \multirow{5}{*}{ Income Group } & Less than 5 Lacs & 72 & 38.1 \\
\cline { 2 - 4 } & $5,00001-10,00000$ & 65 & 34.4 \\
\cline { 2 - 4 } & $10,00001-15,00000$ & 18 & 9.5 \\
\cline { 2 - 4 } & Above 15,00001 & 34 & 18.0 \\
\hline
\end{tabular}

Table 2. Awareness of E-insurance

\begin{tabular}{|l|l|l|}
\hline Awareness & No. of Respondents & Percentage \\
\hline Yes & 141 & 75 \\
\hline No & 48 & 25 \\
\hline
\end{tabular}

Table 3. Criterion for choosing insurance policy

\begin{tabular}{|l|l|l|}
\hline Criterion for choosing policy. & No. of Respondents & Percentage \\
\hline On recommendation of agent & 53 & 28.0 \\
\hline Chosen online & 66 & 34.9 \\
\hline After consulting with family & 70 & 37.0 \\
\hline
\end{tabular}

Table 3 shows that 37 percent of the respondents have chosen their policies after consulting their family members, it is observed that while 75 percent of our respondents are aware of Einsurance in total (Table 2), only 34.9 percent of the respondents are choosing their policies online.

\subsection{Beneficial Factors Affecting Adoption of E-insurance}

Table 4. Reliability Statistics

\begin{tabular}{|l|l|}
\hline Cronbach's Alpha & N of Items \\
\hline .936 & 20 \\
\hline
\end{tabular}


Table 5. KMO and Bartlett's test

\begin{tabular}{|l|l|l|}
\hline \multicolumn{2}{|l|}{ Kaiser-Meyer-Olkin Measure of Sampling Adequacy. } & .921 \\
\hline Bartlett’s Test of Sphericity & Approx. Chi-Square & $2.150 \mathrm{E} 3$ \\
\cline { 2 - 3 } & df & 190 \\
\cline { 2 - 3 } & Sig. & .000 \\
\hline
\end{tabular}

Table 6. Statements with their loadings

\begin{tabular}{|c|c|c|c|c|c|}
\hline Factor & Statements included in the factor & Loading & $\begin{array}{l}\text { Eigen } \\
\text { Value }\end{array}$ & $\begin{array}{l}\text { Variation } \\
\text { caused }\end{array}$ & $\begin{array}{l}\text { Cumulative } \\
\text { Variance }\end{array}$ \\
\hline \multirow[t]{7}{*}{ Sustainability } & $\begin{array}{l}\text { E-insurance is all about promoting } \\
\text { environmental friendly practices }\end{array}$ & .810 & 9.348 & 21.810 & 21.810 \\
\hline & $\begin{array}{l}\text { There is no need of manually completing } \\
\text { forms }\end{array}$ & .704 & & & \\
\hline & E-insurance helps in sustainable development & .647 & & & \\
\hline & E-insurance is fully secured & .634 & & & \\
\hline & $\begin{array}{l}\text { E-insurance avoids paper work as much as } \\
\text { possible }\end{array}$ & .626 & & & \\
\hline & $\begin{array}{l}\text { E-insurance requires digital signatures which } \\
\text { are fail-safe }\end{array}$ & .617 & & & \\
\hline & $\begin{array}{l}\text { There is no risk of loss or damage of the } \\
\text { policy certificates }\end{array}$ & .605 & & & \\
\hline \multirow[t]{8}{*}{ Cost Effective } & $\begin{array}{l}\text { E-insurance reduces the cost of internal } \\
\text { administration. }\end{array}$ & .762 & 1.301 & 21.069 & 42.879 \\
\hline & $\begin{array}{l}\text { E-insurance reduces the management costs } \\
\text { permitting real-time networking of company } \\
\text { departments }\end{array}$ & .723 & & & \\
\hline & $\begin{array}{l}\text { E-insurance is beneficial for enhancing } \\
\text { business of insurance providers }\end{array}$ & .695 & & & \\
\hline & E-insurance involves Self operation & .682 & & & \\
\hline & $\begin{array}{l}\text { E-insurance reduces commission paid to } \\
\text { intermediaries since it can be sold directly to } \\
\text { clients }\end{array}$ & .641 & & & \\
\hline & Ease of paying and receiving related funds & .621 & & & \\
\hline & $\begin{array}{l}\text { E-insurance helps in improving transparency } \\
\text { in operations }\end{array}$ & .564 & & & \\
\hline & $\begin{array}{l}\text { It reduces the frequency of being physically } \\
\text { present in the insurance offices }\end{array}$ & .501 & & & \\
\hline \multirow[t]{5}{*}{$\begin{array}{l}\text { Operational } \\
\text { benefit }\end{array}$} & $\begin{array}{l}\text { E-insurance helps the buyers in comparing } \\
\text { and choosing the best policy from a wide } \\
\text { range of prices and policy conditions }\end{array}$ & .696 & 1.146 & 16.098 & 58.977 \\
\hline & $\begin{array}{l}\text { Consolidation of all the policies in a single } \\
\text { account is of great help }\end{array}$ & .650 & & & \\
\hline & $\begin{array}{l}\text { E-insurance helps in improving management } \\
\text { information }\end{array}$ & .604 & & & \\
\hline & $\begin{array}{l}\text { E-insurance is better as compared over } \\
\text { traditional method in terms of buying }\end{array}$ & .598 & & & \\
\hline & $\begin{array}{l}\text { Demat of policies makes it easier to track the } \\
\text { policy and ensure that it reaches the buyer }\end{array}$ & .480 & & & \\
\hline
\end{tabular}


Extraction Method: Principal Component Analysis.

Rotation Method: Varimax with Kaiser Normalization.

Cronbach's Alpha was calculated to check the reliability of the scale and its value was found to be .936 (Table 4), ensuring reliability of the used scale. A sample of 189 observations against 20 variables was taken into consideration, thus qualifying the adequate sample size requirement for stable factor solution. The Measure of sampling adequacy value (MSA )falls in the acceptable range (above 0.50) with a value of 0.921 for KMO and 0.000 for Bartlett's test (less than 0.5) (Table 5) which ensures the stability and appropriateness of the collected data for the application of the factor analysis (Hair et al., 2010). Eigen value represents the total variance explained by each factor and the standard practice normally used is that all the factors with an Eigen value of one or more should be extracted (Gorsuch, 1983). By using Principal component analysis (PCA), only three components emerged with the Eigen values greater than 1 . The results were obtained through varimax method and all the factors with loadings greater than 0.45 has been retained (Table 6).

The three factors extracted, explained a total variation of 58.97 percent. The first factor comprised of variables-promoting environmental friendly practices, no need of manually completing forms, helps in sustainable development, no paper work required, requires digital signatures, no risk of loss or damage of the policy certificates. The factor was named as "sustainable benefits" and explained 21.810 percent of variation. The second factor comprised of variables - reduces the cost of internal administration, reduces the management costs, beneficial for enhancing business of insurance providers, involves Self operation, reduces commission paid to intermediaries, Ease of paying and receiving related funds, helps in operational transparency and reduces the frequency of being physically present in the insurance offices. This factor was named as "Cost effective" and accounted for 21.069 percent of variation. The third factor comprised of variables- helps the buyers in comparing and choosing the best policies, helps consolidating the policies in a single account, helps in improving management information, easy when compared over traditional methods and Demat makes tracking of policy easier. This factor was named as “Operational Benefits” and it accounted for 16.098 percent of variation.

Table 7. Reliability test

\begin{tabular}{|l|l|}
\hline Cronbach's Alpha & N of Items \\
\hline .908 & 14 \\
\hline
\end{tabular}

Table 8. KMO and Bartlett's test

\begin{tabular}{|c|c|c|}
\hline \multicolumn{2}{|c|}{ Kaiser-Meyer-Olkin Measure of Sampling Adequacy. } & .875 \\
\hline Bartlett's Test of Sphericity & Approx. Chi-Square & $1.356 \mathrm{E} 3$ \\
\cline { 2 - 3 } & $\mathrm{df}$ & 91 \\
\cline { 2 - 3 } & Sig. & .000 \\
\hline
\end{tabular}


Table 9. Statements with their loadings

\begin{tabular}{|c|c|c|c|c|c|}
\hline Factor & Statements included in the factor & Loading & $\begin{array}{l}\text { Eigen } \\
\text { Value }\end{array}$ & $\begin{array}{l}\text { Variation } \\
\text { Caused }\end{array}$ & $\begin{array}{l}\text { Cumulativ } \\
\text { e variance }\end{array}$ \\
\hline \multirow[t]{4}{*}{ Security related issues } & $\begin{array}{l}\text { Security is an issue with customers } \\
\text { regarding fear of loss of confidential } \\
\text { information such as username and } \\
\text { password }\end{array}$ & .817 & 6.479 & 22.014 & 22.014 \\
\hline & $\begin{array}{l}\text { Privacy is an issue in case of an } \\
\text { e-insurance }\end{array}$ & .816 & & & \\
\hline & $\begin{array}{l}\text { Illegality of electronic signatures is a } \\
\text { challenge sometimes }\end{array}$ & .674 & & & \\
\hline & $\begin{array}{l}\text { Sharing of database of customers by the } \\
\text { company }\end{array}$ & .533 & & & \\
\hline \multirow[t]{4}{*}{ Customer related issues } & $\begin{array}{l}\text { Lack of knowledge about repositories is } \\
\text { also a constraint }\end{array}$ & .760 & 1.310 & 20.659 & 42.674 \\
\hline & $\begin{array}{l}\text { Lack of knowledge of using internet } \\
\text { also becomes a constraint }\end{array}$ & .710 & & & \\
\hline & $\begin{array}{l}\text { There is a lack of awareness regarding } \\
\text { E-insurance among customers }\end{array}$ & .525 & & & \\
\hline & $\begin{array}{l}\text { E-insurance involves reluctance } \\
\text { /resistance on the part of customers to } \\
\text { change from traditional methods }\end{array}$ & .500 & & & \\
\hline \multirow[t]{6}{*}{ Insurer related issue } & $\begin{array}{l}\text { E-insurance policies do not provide a } \\
\text { discount on premium (as in agent based } \\
\text { system) }\end{array}$ & .836 & 1.061 & 20.538 & 63.212 \\
\hline & $\begin{array}{l}\text { E insurance policies cannot be } \\
\text { customized as per the needs and } \\
\text { requirement of the customers }\end{array}$ & .618 & & & \\
\hline & $\begin{array}{l}\text { Unlike traditional methods, there is lack } \\
\text { of push from insurers and } \\
\text { intermediaries }\end{array}$ & .564 & & & \\
\hline & $\begin{array}{l}\text { There is difficulty in data shifting in } \\
\text { case of movement from one repository } \\
\text { to another }\end{array}$ & .561 & & & \\
\hline & $\begin{array}{l}\text { There is lack of proper web based } \\
\text { mechanism for protecting claims }\end{array}$ & .556 & & & \\
\hline & $\begin{array}{l}\text { Insurers selling online directly to clients } \\
\text { are offering a very restricted portfolio } \\
\text { of products }\end{array}$ & .517 & & & \\
\hline
\end{tabular}

In this case, Table 7 indicates that Cronbach's Alpha is .908, which ensures reliability of the used scale. A sample of 189 observations against 14 variables was taken into consideration, thus qualifying the adequate sample size requirement for stable factor solution. The Measure of sampling adequacy value (MSA) falls in the acceptable range (above 0.50) with a value of .875 for KMO and .000 for Bartlett's test (less than 0.5) (Table 8) ensuring the stability and appropriateness of the collected data. By using Principal component analysis (PCA), only three components emerged with the Eigen values greater than 1. Using Varimax method, all factors with loadings greater than 0.45 have been retained.

Three factors which have been extracted (Table 9), explained 63.212 percent of total variation. The first factor comprised of variables-issue with customers regarding fear of loss of confidential information, Privacy, Illegality of electronic signatures, Sharing of database of customers. The factor was named as "Security Related issues" and explained 22.014 percent 
of variation. The second factor comprised of variables - Lack of knowledge about repositories, Lack of knowledge of using internet lack of awareness regarding E-insurance among customers, Customers reluctance to switch over from traditional methods. This factor was named as "Customer related issues" and accounted for 20.659 percent of variation. The third factor comprised of variables-policies do not provide a discount on premium, not customized, lack of push from insurers and intermediaries, difficulty in data shifting in case of movement from one repository to another, lack of proper web based mechanism, offering a very restricted portfolio of products online. This factor was named as "Insurer related issues" and it accounted for 20.538 percent of variation.

\subsection{Relationship between Various Demographic Variables and Perception towards E-Insurance}

Empirical studies have focused on relation between demographic profile of investors and e-insurance adoption readiness (Bromideh, 2012). In order to test the same, following null hypothesis has been formulated.

H01: Various demographic variables (Age, Gender and Income Level) do not affect the respondents' perception of various factors affecting adoption of E-insurance.

The hypothesis was tested through one way ANOVA using SPSS 20.0 version and the results are summarized in Table 10:

Table 10. Analysis of variance (ANOVA) between different demographic variables and customer's perception towards E-Insurance

\begin{tabular}{|l|l|l|l|l|l|l|l|}
\hline $\begin{array}{l}\text { Demographic } \\
\text { Variable }\end{array}$ & & & $\begin{array}{l}\text { Sum of } \\
\text { Squares }\end{array}$ & df & $\begin{array}{l}\text { Mean } \\
\text { Square }\end{array}$ & F & Sig. \\
\hline \multirow{4}{*}{ Age } & Sustainability benefits & Between Groups & 5.312 & 4 & 1.328 & 1.338 & .258 \\
\cline { 2 - 8 } & Cost Benefits & Between Groups & 3.749 & 4 & .937 & .936 & .444 \\
\cline { 2 - 8 } & Operational Benefits & Between Groups & 6.785 & 4 & 1.696 & 1.722 & .147 \\
\hline \multirow{3}{*}{ Gender } & Sustainability benefits & Between Groups & 2.126 & 1 & 2.126 & 2.139 & .145 \\
\cline { 2 - 8 } & Cost Benefits & Between Groups & .084 & 1 & .084 & .084 & .772 \\
\cline { 2 - 8 } & Operational Benefits & Between Groups & .938 & 1 & .938 & .938 & .334 \\
\hline Income Level & Sustainability benefits & Between Groups & 18.521 & 3 & 6.174 & 6.739 & .000 \\
\cline { 2 - 8 } & Cost Benefits & Between Groups & 4.846 & 3 & 1.615 & 1.632 & .184 \\
\cline { 2 - 8 } & Operational Benefits & Between Groups & 4.537 & 3 & 1.512 & 1.525 & .210 \\
\hline
\end{tabular}

In Table 10, the results of ANOVA between demographic profile of investors and perception towards E-insurance indicate that null hypothesis has been accepted for age and gender as these two variables do not affect the respondents' perception of various factors affecting adoption. The results are contrary to Bromideh (2012), who found age to be a negative factor in e-insurance adoption. For the variable, income level, the null hypothesis is partially rejected for primarily one factor i.e., "sustainability benefits", as income level is found to have significant impact on the factor "sustainability benefits". This means perception of 
people about the factor varies across different income levels.

Table 11. Analysis of variance (ANOVA) between different demographic variables and perceived issues in using in using E-Insurance

\begin{tabular}{|l|l|l|l|l|l|l|l|}
\hline $\begin{array}{l}\text { Demographic } \\
\text { Variable }\end{array}$ & & & $\begin{array}{l}\text { Sum of } \\
\text { Squares }\end{array}$ & df & $\begin{array}{l}\text { Mean } \\
\text { Square }\end{array}$ & F & Sig. \\
\hline \multirow{3}{*}{ Age } & Security related & Between Groups & 6.532 & 4 & 1.633 & 1.656 & .162 \\
\cline { 2 - 8 } & Customer oriented & Between Groups & 6.105 & 4 & 1.526 & 1.544 & .191 \\
\cline { 2 - 8 } & Insurer related & Between Groups & 2.744 & 4 & .686 & .681 & .606 \\
\hline \multirow{3}{*}{ Gender } & Security related & Between Groups & 2.790 & 1 & 2.790 & 2.817 & .095 \\
\cline { 2 - 8 } & Customer oriented & Between Groups & 1.620 & 1 & 1.620 & 1.625 & .204 \\
\cline { 2 - 8 } & Insurer related & Between Groups & .904 & 1 & .904 & .904 & .343 \\
\hline Income Level & Security related & Between Groups & 3.192 & 3 & 1.064 & 1.065 & .365 \\
\cline { 2 - 8 } & Customer oriented & Between Groups & 17.776 & 3 & 5.925 & 6.440 & .000 \\
\cline { 2 - 8 } & Insurer related & Between Groups & 1.257 & 3 & .419 & .415 & .742 \\
\hline
\end{tabular}

Table 11 indicated that in case of the variable "income levels", null hypothesis has been partially rejected for primarily one factor "customer oriented". Also, it is found that other two factors namely age and gender; do not have any impact on the perceived issues in using E-insurance.

\section{Conclusion}

In the present era of sustainable development, the green practices are being advocated worldwide. A number of technological innovations are facilitating this initiative to "go green". Using Information and Communication Technology (ICT) to the aid of insurance sector, with a focus on using less/no paper and maintaining the records in electronic form, is an initiative on its own accord. Though research in the context of insurance sector as whole and internet/e-commerce applications had already been there, but there is still paucity of research studies from the perspectives of customer. The present customer focused study aimed at finding out various factors affecting adoption of E-Insurance and various issues that bother a customer while using e-insurance. Using a sample size of 189 respondents, the study results in extraction of three factors affecting adoption of E-insurance. These three factors namely "sustainability", "cost effective" and "operational benefits" are found to be the major factors influencing the adoption of E-insurance in Indian context. Along with this, there are three issues perceived by the customers in using E-insurance viz. a viz. "security related", "customer oriented" and "Insurer related". Investigating the impact of various demographic variables, the study does not witness any impact of age and gender on the factors affecting adoption and perceived issues in E-insurance. Only variable that has impacted these factors and perceived issue is income level. Respondents in different income brackets differ on their perception regarding the factor "sustainability benefits" and the "Customer oriented" issue.

The managerial implications of the study are numerous. Insurers should not only invest on implementation of E-insurance but also they should create the awareness about E-insurance 
and educational campaigns for the insured should be organized to explain the procedure as to how to use the Internet to buy a policy online. Study identifies some "customer oriented" issues, which basically include lack of awareness, knowledge and willingness to use E-insurance, which must be focused upon by the insurers. Security appeared to be an issue which should be addressed by insurers by educating them about how E-insurance is a secured option. Also, when "sustainability" has appeared be one factor affecting E-banking adoption, promoting E-insurance with its linkage with environmental benefits and thereby contributing to go-green initiatives could be done.

Overall, present research has a limitation of smaller sample size for its generalizability to whole of India. Future research studies may focus on drawing a sample from pan India, using a more appropriate sampling technique. Further researchers may extend this study by conducting it insurer-wise. The basic rationale of E-insurance is to eliminate the brick and mortar institutions and making, buying, managing and selling the insurance work completely online. The researches to be conducted may focus on finding out the extent of adoption of the E-insurance in India or the separate research may be conducted on slow adoption of E-insurance, problems encountered in using it or perceived challenges.

\section{References}

Aarabi, N., \& Bromideh, A. A. (2006). The Impact of e-Commerce on the Iranian Insurance Companies. MSc. Dissertation, Lulea University of Technology. [Online] Available: http://epubl.ltu.se/1653-0187/2006/03/index-en.html

Alipour, M., Dorodi, H., \& Pishgahi, S. (2011). Feasibility Study of E-Insurance Services in Iranian Insurance Companies (Asia Insurance Co.). International Journal of Business and Social Science, 2(10).

Arora, A. (2003). E-Insurance: Analysis of the Impact and Implications of Ecommerce on the Insurance Industry Dissertation submitted for the award of Msc in Actuarial Management.

Banan, M. (2009). How is E-Insurance in Developing Countries? Georgian Electronic Scientific Journal: Computer Science and Telecommunications, 5(22), 116-137.

Bromideh, A. A. (2012). Factors Affecting Customer E-Readiness to Embrace Auto E-Insurance in Iran. Journal of Internet Banking and Commerce, 17(1), 1-12.

CII Report (2015). Indian Insurance Sector: Building Growth, Building Value. [Online] Available:

http://www.ey.com/Publication/vwLUAssets/ey-building-growth-and-value-in-the-insurancesector/\$FILE/ey-building-growth-and-value-in-the-insurance-sector.pdf

Dasgupta, P., \& Sengupta, K. (2002). E-Commerce in the Indian Insurance Industry. Electronic Commerce Research, 2, 43-60. http://dx.doi.org/10.1023/A:1013335901218

Dash, S. K., \& Pany, T. K. (2013). Insurance Industry in India-Prospects and Challenges. Asian Journal of Multidimensional Research, 2(4), 46-64.

Dwivedi, S. K., \& Bharti, A. K. (2010). E-Governance in India-Problems and Acceptability. 
Journal of Theoretical and Applied Information Technology, 17(1), 37-43.

Ernest \& Young Report. (2012). Insurance Industry Challenges, Reforms and Realignment [Online] Available: http://www.ey.com/Publication/vwLUAssets/Insurance_industry_-_challenges_reforms_and_ realignment/\$FILE/EY-Insurance-industry-challenges-reforms-realignment.pdf

Esfahani, S. A., Ghasemi, M., \& Nozaripour, J. (2014). Evaluation of Effective Factors on Customers' Willingness to Buy Electronic Insurance. Indian Journal of Scientific Research, 6(1), 218-221.

Fakhri, P., Hajighafori, F., \& Jafarzadeh, J. (2014). The Role of Electronic-insurance and Electronic Commerce in Expansion of Insurance Companies, Kuwait Chapter of Arabian. Journal of Business and Management Review, 3(10a), 70-79.

Gorsuch, R. L. (1983). Factor analysis. Hillsdale, New Jersey: Lawrence Erlbaum Associates.

Grossman, M., McCarthy, R. V., \& Aronson, J. E. (2004). E-Commerce Adoption in the Insurance Industry. Issues in Information Systems, $V(2)$.

Hair, J. F., Black, W. C., Babin, B. J., \& Anderson, R. E. (2010). Multivariate Data analysis. New Jersey: Pearson Education.

Hariharaputhiran, S. (2012). Challenges and Opportunities of E-Commerce. International Journal of Marketing, Financial Services \& Management Research, 1(3), 98-108.

Hiwarkar, T., \& Khot, P.G. (2013). E-Insurance: Analysis of the Collision and Allegation of E-Commerce on the Insurance and Banking. Journal of Business Management \& Social Sciences Research (JBM\&SSR), 2(6).

Keivani, F. S., Almasi, M. R., Sourkouhi, Z. K., Makouei, S., \& Bayat, M. (2013). An Investigation of the Internet Effects on Business. Scandinavian Journal of Immunology, 13(6), 96-99.

Krishnamurthy, S., Mony, S. V., Jhaveri, N., Bakhshi, S., Bhat, R., Dixit, M. R., \& Maheshwari, S. (2005). Insurance Industry in India: Structure, Performance, and Future Challenges. Vikalpa the Journal for Decision Makers, 30(3), p.93.

Mauricio, S., Featherman, J., Valacich S., \& Wells, D. J. (2006). Is that authentic or artificial? Understanding consumer perceptions of risk in e-service encounters. Inforamtion System Journal, 16, 107-134. http://dx.doi.org/10.1111/j.1365-2575.2006.00211.x

Meshkat, L., Farkhondehnia, F., Bagheri, Z., Alihoseini, O., Sanayeimatak, S., Esmaeili, M., ...Masaratbakhsh, M. (2012). Electronic Insurance and its application in e-commerce. Interdisciplinary Journal of Contemporary Research In Business, 4(8).

Oblinger, D. (2001). Will E-business Shape the Future of Open and Distance Learning? Open Learning, 16(1), 9-25. http://dx.doi.org/10.1080/02680510124360 


\section{Macrothink}

Case Studies in Business and Management

ISSN 2333-3324

2016, Vol. 3, No. 1

Odoyo, F. S., \& Nyangosi, R. (2011). E-Insurance: An Empirical Study of Perceived Benefits. International Journal of Business and Social Science, 2(21).

Phichitchaisopa, N., \& Naenna, T. (2013), Factors Affecting the Adoption of Healthcare Information Technology. EXCLI Journal, 12(1), 13-436.

Raghunath, A., \& Panga, M. D. (2013). Problem and Prospects of E-Commerce. International Journal of Research and Development-A Management Review (IJRDMR), 2(1), 59-68.

Rakovska, G. (2011). E-Commerce Business Models for Insurance: Application to U.S. and European Markets. Centre for Risk Management \& Insurance Research, 2011.

Salehi, M., \& Alipour, M. (2010). E-Banking in Emerging Economy: Empirical Evidence of Iran. International Journal of Economics and finance, 2(1), 201-209. http://dx.doi.org/10.5539/ijef.v2n1p201

Sanayei, A., Torkestani, M. S., \& Ahadi, P. (2009). Readiness Assessment of Iran's Insurance Industry for E-Commerce and E-Insurance Success. International Journal of Information Science \& Management, 7(1), 91-105.

Taylor, A. S., Celuch, K., \& Goodwin. S. (2002). Technology Readiness in the e-Insurance Industry: An Exploratory Investigation and Development of an Agent Technology e-Consumption Model. Journal of Insurance Issues, 25(2), 142-165.

Yao, J. T. (2004). E-commerce adoption of insurance companies in New Zealand. Journal of Electronic Commerce Research, 5(1).

Yu, C. (2012). Factors Affecting Individuals to Adopt Mobile Banking: Empirical Evidence from the Utaut Model. Journal of Electronic Commerce Research, 13(2), 104-121.

\section{Copyright Disclaimer}

Copyright for this article is retained by the author(s), with first publication rights granted to the journal.

This is an open-access article distributed under the terms and conditions of the Creative Commons Attribution license (http://creativecommons.org/licenses/by/3.0/). 